\title{
Employability Skills of Vocational High School Expertise Mechanical Engineering at Surakarta City
}

\author{
Fendy Wijarwanto*, Bernardus Sentot Wijanarka \\ Department of Mechanical Engineering Education, Graduate School, Yogyakarta State University \\ *Corresponding author: fwijarwanto@gmail.com \\ Received October 01, 2019; Revised November 08, 2019; Accepted November 11, 2019
}

\begin{abstract}
This research aims to find out 1) customer satisfaction index, 2) important employability skills aspects which expected by industries or users of mechanical engineering vocational high school. This research is a quantitative descriptive study that uses the customer satisfaction index approach and Importance Performance Analysis. The subject of this research is the industry with the Human Resource Manager or Production Manager as respondent. The result of the satisfaction index is $76.98 \%$. This value is within the satisfied range, it's mean industry expectations are full fill by grading. Importance employability skills aspects expected by industries are job or duty respect (3.56), discipline $(3.55)$, honesty $(3,45)$, technical design ability $(3.44)$, operate and programming CNC Machine (3.40), operate manual machine (3.33), caring (3.33), using software design (3.22), creativity (3.22), communication (3.11), collaboration (3.11), and automation (3.00). Base on importance-performance analysis indicators job or duty respect and technical design ability are in the quadrant I. Discipline, honesty, concern, operate dan programming CNC, and operate the manual machine are in quadrant II. Communication, creativity and automation are in quadrant III. Using software design and collaboration are in quadrant IV.
\end{abstract}

Keywords: quality insurance, competency, soft skill, TVET, quality management

Cite This Article: Fendy Wijarwanto, and Bernardus Sentot Wijanarka, "Employability Skills of Vocational High School Expertise Mechanical Engineering at Surakarta City.” American Journal of Educational Research, vol. 7, no. 11 (2019): 800-805. doi: 10.12691/education-7-11-7.

\section{Introduction}

The 21st century requires new skills that must be possessed by vocational high school (VHS) or VHS graduates. These skills will be needed by graduates to compete in the industry. The four skills needed in competition in the 21st century are critical thinking, collaboration, communication, and creativity. Aspects of critical thinking are justified by revisions with evidence, create new products, think scientifically, evaluate and make arguments. Aspects of collaboration include polite and respect for colleagues, respect and positive thinking, following the work rules. Communication aspects include efficiency in meetings, being able to organize information, speak clearly and logically. Creative aspects include understanding how knowledge can be applied according to context, helping teams, conflict management, managing communication to get the job done better [1].

The technological change in the mechanical engineering sector in terms of smart systems is divided into three categories, namely cutting edge control technologies, advanced machine learning, machine functions close to human perception, cognition, and behavior. The generic skills needed to deal with these changes are flexibility in dealing with technological changes and high adaptation. Qualitative skills needed are mastery of ICT, electronic-mechanics or mechatronics [2].

The impacts of technological change in the industry is a change in the number of workers, types of work and qualifications of workers. To encourage changes in vocational education, the government issued a presidential instruction (Inpres) on Vocational High School revitalization. The purpose of this revitalization is to improve the competitiveness and quality of human resources [3]. By increasing the quality of human resources, graduates are expected to be able to compete in the world of work.

Based on data from the Central Statistics Agency, the number of the labor force in Indonesia in 2018 is 131.01 million and as many as 124.01 million are workers. Of the 7 million unemployed, $11.24 \%$ are vocational high school graduates. When compared to 2015 generally there was a decrease in the contribution of unemployment. Data from 2015 showed that the percentage of unemployed was 12.65\%; in 2016 decreased to $11.11 \%$; 2017 increased to $11.41 \%$, and 2018 became $11.24 \%$ [4].

The Minister of Development Planning / Head of Bapenas said that the cause of this high unemployment rate of VHS graduates is due to the gap or gap between the competencies needed by the industry and curriculum and the implementation of learning in VHS [5]. Business and industry have a very important role in reducing the gap that occurs in VHS. Business and industry have a very 
important role in reducing the gap that occurs in SMK. Some of the business and industrial activities carried out in the city of Mataram with the implementation of the apprenticeship, teacher training, industry involved in competency testing and curriculum development in the form of curriculum workshops [6].

In the teaching process, there is also a gap between what is done with the development of the industrial world. Some of the gaps include in terms of curriculum suitability, soft skills learning, and completeness of infrastructure [7]. Schools whose graduates are accepted in the industry are schools that compile their curriculum based on the needs of the industrial world. The curriculum applied at VHS has a $72 \%$ relevance to the competency needs of the industrial world, in this case, it is considered quite relevant. $52.3 \%$ of students' learning material is very relevant to the industrial world and $47.7 \%$ is quite relevant [8]. The school carries out various activities to reduce disparities with industry. Some of the activities carried out are cooperation with business and industry, collaboration with alumni, career guidance, and professional certification. These efforts will not necessarily be able to improve the soft skills and motivation of graduates to work [9].

In the industrial world, especially manufacturing, in addition to technical skills or competencies, non-technical abilities or soft skills are also needed to support the work process. Non-technical abilities include communication skills, leadership, teamwork, mastery of information technology, management skills and problem-solving. The non-technical abilities mentioned above from the perception of manufacturing industry employees in Malaysia states that communication skills are important to master [10].

The results of the study stated that graduates still need additional knowledge and experiences from industry to work better. Improving the quality of graduates can only be done by improving the quality of education that involves stakeholders in the business and industrial world, schools are declared qualified if they can meet the needs of its users [11]. The work readiness and motivation of VHS graduates in Bandung are very satisfying while the commitment of graduates has not been satisfactory for the industry. The technical aspects of graduates are satisfactory, but not in line with industry expectations [12].

Based on the above background, it is necessary to research the aspects of work skills needed and the level of industry satisfaction. By knowing aspects of these top priorities, schools should immediately make improvements to the curriculum, process and learning strategies.

\section{Research Methodology}

The research method used is descriptive quantitative. Data collection using a questionnaire, graduated data from VHS. The subjects of this study were industrial users of graduates who were in 4 provinces as in Table 1, with respondents HRD Manager or Production Manager. Graduate data is taken from 6 schools in the city of Surakarta, namely (1) SMK Katolik St. Mikael Surakarta, (2) SMK Warga Surakarta, (3) SMK Muhammadiyah 1 Surakarta, (4) SMKN 2 Surakarta (5) SMKN 2 Surakarta dan (6) SMKN 5 Surakarta. The techniques used in analyses are literature review, customer satisfaction index and importance-performance analysis. The literature review is used to determine aspects of work abilities. The customer satisfaction index is used to determine the level of satisfaction of graduates' work abilities The customer satisfaction index is used to determine the level of satisfaction of graduates' ability to work. Importance performance analysis is used to determine the aspects of work abilities that are most needed by industry and are not met by graduates, so schools can take appropriate corrective action plans [13]

Table 1. List of Respondents

\begin{tabular}{lll}
\hline No & Institution Name & Location \\
\hline 1 & PT Trimedya Primatech & Tangerang Banten \\
\hline 2 & PT Rapid Plast Indonesia (plant 2) & Cikarang, Jawa Barat \\
\hline 3 & PT CG Power Systems Indonesia & Bogor Jawa Barat \\
\hline 4 & PT Santoso Teknindo & Tangerang Banten \\
\hline 5 & PT. Maha Tandra & Bandung, Jawa Barat \\
\hline 6 & PT Rapid Plast Indonesia (plant 1) & Sidoarjo, Jawa Timur \\
\hline 7 & PT Sinde Budi Sentosa & Jawa Barat \\
\hline
\end{tabular}

\section{Result and Discussion}

\subsection{Data Description of VHS Expertise Mechanical Engineering Outcome}

The data of graduates are from 6 VHS expertise mechanical engineering in Surakarta City academic year 2017/2018 and 2018/2019. Table 2 presents graduate data for 2 years, the number of graduates in 2019 has increased by 3\% compared to 2018. The target of the Directorate of VHS 75\% of graduates in 2018 and 2019 getting a job, $5 \%$ self-employed and $20 \%$ continue to study [14].

Table 2. VHS Expertise Mechanical Engineering of Surakarta City

\begin{tabular}{|c|l|c|c|}
\hline \multirow{2}{*}{ No } & \multirow{2}{*}{ Name of VHS } & \multicolumn{2}{|c|}{ Number Of Graduates } \\
\cline { 3 - 4 } & & Year 2018 & Year 2019 \\
\hline 1 & SMK Katolik St. Mikael Surakarta & 159 & 166 \\
\hline 2 & SMK Warga Surakarta & 151 & 151 \\
\hline 3 & SMK Muhammadiyah 1 Surakarta & 56 & 62 \\
\hline 4 & SMKN 2 Surakarta & 126 & 125 \\
\hline 5 & SMKN 5 Surakarta & 124 & 124 \\
\hline 6 & SMK Murni 1 Surakarta & 28 & 31 \\
\hline
\end{tabular}

Tracing data of graduates is divided into several categories which are namely working, continue to higher education level, making own business, jobless, and unregistered. In Table 3 it can be seen that in 2018, 414 graduates were employed, 207 graduates continue to college or university, 6 graduates do business, 10 graduates unemployment and 7 graduates no registered. In 2019 the number of graduates employed was 411 people, 204 graduates continue to college or university, 5 entrepreneurs, 23 unemployed people, and 15 people were not registered. 
Table 3. Data of VHS Expertise Mechanical Engineering of Surakarta City

\begin{tabular}{|c|c|c|c|c|c|c|c|c|c|c|c|}
\hline \multirow[b]{2}{*}{ No } & \multirow[b]{2}{*}{ Name of VHS } & \multicolumn{2}{|c|}{ Work/ employed } & \multicolumn{2}{|c|}{ Continue to University } & \multicolumn{2}{|c|}{ Entrepreneur } & \multicolumn{2}{|c|}{ Unemployed } & \multicolumn{2}{|c|}{ No Data } \\
\hline & & $\begin{array}{l}\text { Year } \\
2018\end{array}$ & $\begin{array}{l}\text { Year } \\
2019\end{array}$ & Year 2018 & $\begin{array}{l}\text { Year } \\
2019\end{array}$ & $\begin{array}{l}\text { Year } \\
2018\end{array}$ & $\begin{array}{l}\text { Year } \\
2019\end{array}$ & $\begin{array}{l}\text { Year } \\
2018\end{array}$ & $\begin{array}{l}\text { Year } \\
2019\end{array}$ & $\begin{array}{l}\text { Year } \\
2018\end{array}$ & $\begin{array}{l}\text { Year } \\
2019\end{array}$ \\
\hline 1 & SMK Katolik St. Mikael Surakarta & 44 & 57 & 115 & 109 & 0 & 0 & 0 & 0 & 0 & 0 \\
\hline 2 & SMK Warga Surakarta & 100 & 100 & 40 & 42 & 1 & 1 & 10 & 8 & 0 & 0 \\
\hline 3 & SMK Muhammadiyah 1 Surakarta & 48 & 53 & 6 & 8 & 0 & 0 & 0 & 0 & 2 & 1 \\
\hline 4 & SMKN 2 Surakarta & 98 & 89 & 26 & 26 & 1 & 2 & 0 & 5 & 1 & 2 \\
\hline 5 & SMKN 5 Surakarta & 98 & 82 & 18 & 18 & 4 & 2 & 0 & 10 & 4 & 12 \\
\hline 6 & SMK Murni 1 Surakarta & 26 & 30 & 2 & 1 & 0 & 0 & 0 & 0 & 0 & 0 \\
\hline
\end{tabular}

In Figure 1 it can be seen the comparison of graduates in 2018 and 2019. Graduates who get jobs with a maximum duration of 3 months after graduation, had a decrease of $1.7 \%$, graduates who continue to the university had a decreased by $1.3 \%$, graduates of entrepreneurship had a decreased by $0.2 \%$. While for graduates who did not get a job, there was an increase of $1.9 \%$ and there was an increase of $1.2 \%$.

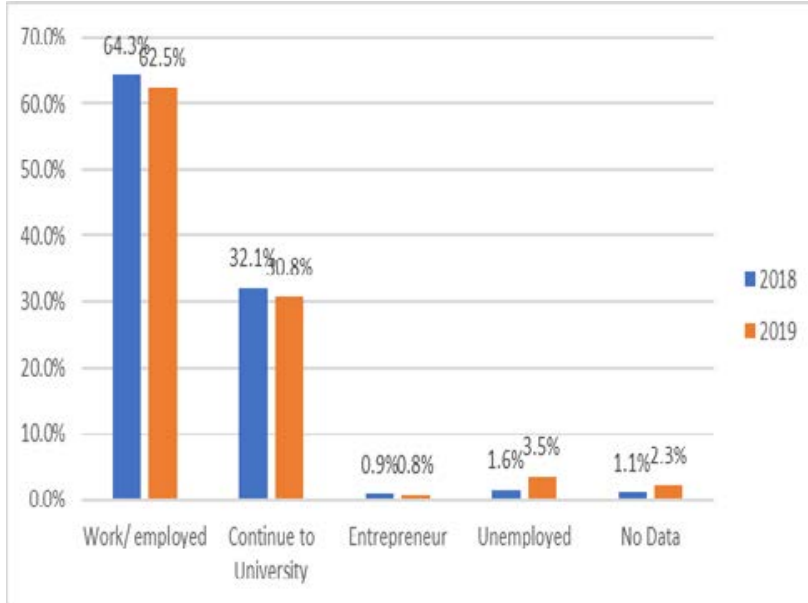

Figure 1. Percentage of VHS Graduates by career category

In Figure 2, we show the relevance of the type of work with graduate competencies. In 2018 graduates who work with required competencies were $58.5 \%$ and without required competencies were $5.7 \%$. In 2019, there was a decrease in the number of graduates without the required field of competence with a value of $4.8 \%$.

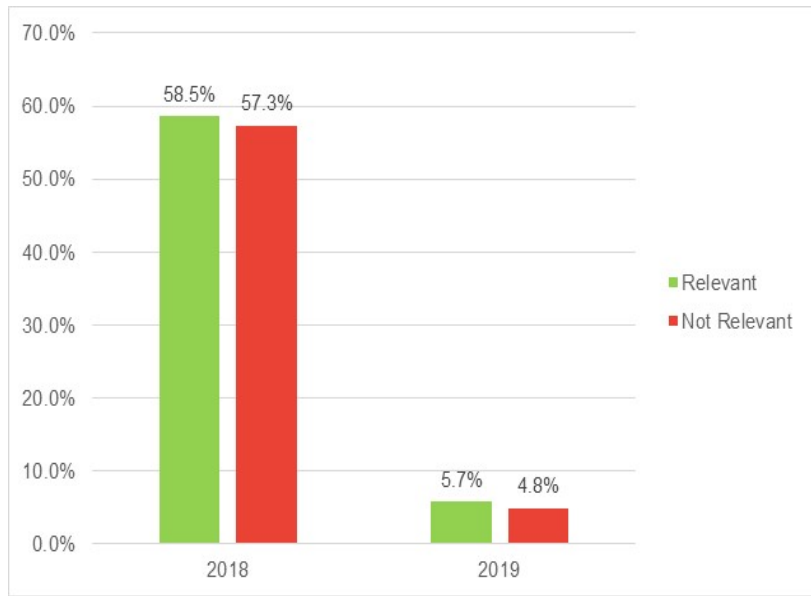

Figure 2. Percentage of Relevance between Graduate Competencies and Employment

\subsection{Employability Skills Aspect}

Competencies that must be mastered by VHS students are regulated in Graduate Competency Standards. These competencies are faith and trust in God, nationality, social and personal character, mental and spiritual health, literacy, creativity, aesthetics, technical ability and entrepreneurship. Graduates' competency standards are translated into competency sub-standards that can be measured and supported by the achievement of graduate competencies. The elaboration is written in the content standard which has a scope in the general content, adaptive content and vocational or expertise [15]. In its operation the content standards are formulated in the curriculum structure of the Vocational School Expertise The curriculum structure program contains subjects learned by students during the learning process, the structure is contained in Table 4 [16].

Table 4. VHS Expertise Mechanical Engineering Curriculum Structure

\begin{tabular}{|c|l|c|}
\hline No & Subject/Competency & Time Duration \\
\hline National Content (Normative and Adaptive) & 318 \\
\hline 1 & Religion and Character & 212 \\
\hline 2 & Citizenship & 320 \\
\hline 3 & Indonesian Language & 424 \\
\hline 4 & Math & 108 \\
\hline 5 & Indonesian History & 352 \\
\hline 6 & English and others & 108 \\
\hline Local Content & 144 \\
\hline 1 & Art & \\
\hline 2 & Sport and Health & \\
\hline Vocational Content & 108 \\
\hline C1. & Basic of Vocational & 108 \\
\hline 1 & Simulation and Digital Communication & 108 \\
\hline 2 & Physics & \\
\hline 3 & Chemistry & 144 \\
\hline C2. & Basic Expertise Program & 180 \\
\hline 1 & Mechanical Engineering Drawing & 144 \\
\hline 2 & Basic Mechanical Engineering Work & 522 \\
\hline 3 & Basic Mechanical Engineering Design & 42016 \\
\hline C3. & Expertise & \\
\hline 1 & Manufacture Engineering Drawing & \\
\hline 2 & Lathe Work & \\
\hline 3 & Milling Work & \\
\hline 4 & Grinding & \\
\hline 5 & NC/CNC and CAM & \\
\hline 6 & Product Development and Entrepreneurship & \\
\hline Total hours for 3 years & \\
\hline
\end{tabular}


Employed graduates are expected to have fundamental skills with the abilities needed to develop a career. Fundamental skills consist of (1) communication, (2) managing information, (3) managing numbers and (4) solving problems [17]. In the implementation of the educational process, the four employability skills are broken down into several sub-dimensions: (1) fundamental skills consisting of communication, managing information, managing numbers and solving problems, (2) personnel Management skills consisting of showing attitudes and behaviors that good, responsible, able to adapt, learn throughout life, work safely and (3) working in a team consists of working with others and participating in projects or tasks. Employability skills are expected to be owned and developed in schools [18].

Table 5. Employability Aspects and Indictors

\begin{tabular}{|c|c|c|}
\hline No & Aspect & Indicators \\
\hline 1 & \multirow{5}{*}{$\begin{array}{l}\text { Technical or } \\
\text { Knowledge-Skills }\end{array}$} & Operate manual machine \\
\hline 2 & & Operate and programming CNC Machine \\
\hline 3 & & Technical design ability \\
\hline 4 & & Using software design \\
\hline 5 & & Automation \\
\hline 6 & \multirow{7}{*}{$\begin{array}{l}\text { Non-technical or } \\
\text { attitude }\end{array}$} & Job or duty respect \\
\hline 7 & & Discipline \\
\hline 8 & & Honesty \\
\hline 9 & & Caring \\
\hline 10 & & Communication \\
\hline 11 & & Collaboration \\
\hline 12 & & Creativity \\
\hline
\end{tabular}

It can be concluded that there are two aspects of employability skills in graduates, namely (1) technical or knowledge-skills Aspects and (2) Non-technical or attitude aspects. Each aspect will be divided into indicators as in Table 5.

\subsection{Satisfaction Index of Graduates Employability Skills}

The method of calculating customer satisfaction is to compare expectations with reality. Customer satisfaction is an index that shows the level of overall customer satisfaction with an approach that considers the importance of the attributes of the product or service being measured [19]. The customer satisfaction index provides data about the level of customer satisfaction so that it can be used to conduct periodic evaluations in the process of improving what is lacking and improving the services that users. The level of customer satisfaction can be seen in Table 6.

Table 6. Criteria for customer satisfaction

\begin{tabular}{ccc}
\hline No & Criteria & Satisfaction Level \\
\hline 1 & $81 \%>\mathrm{X} \leq 100 \%$ & Very satisfied \\
\hline 2 & $66 \%>\mathrm{X} \leq 81 \%$ & Satisfied \\
\hline 3 & $51 \% \geq \mathrm{X} \leq 66 \%$ & Quite satisfied \\
\hline 4 & $35 \% \geq \mathrm{X} \leq 51 \%$ & Less satisfied \\
\hline 5 & $\mathrm{X}<35 \%$ & Not satisfied \\
\hline
\end{tabular}

Data collection for each indicator in the questionnaire was prepared using a Likert scale consisting of 4 scales, namely scale 1 for dissatisfied or unsuitable or unsuitable up to scale 4 which indicated very satisfied or very appropriate or very good. Based on the results of the questionnaire that has been circulated, the customer satisfaction results are obtained as in Table 7.

If the data is calculated using the Customer Satisfaction Index formula, the following results will be obtained: $Y=\sum I$ then $Y=39.67, T=\sum S T=122.15$. Customer satisfaction index $=\frac{T}{4 Y} \times 100 \%=\frac{122.15}{4 \times 39.67} \times 100 \%=$

78.96\%. Based on Table 6 customer satisfaction index criteria, it can be concluded that the industries state SATISFIED with the graduate's employability skills.

\subsubsection{Important Employability Skills}

Determination of aspects of graduate employability skills that are considered important by the industry using the Importance Performance Analysis (IPA) method. This method will be divided into four quadrants, where each quadrant will have different meanings [13]. Calculation $\bar{P}$ and $\bar{I}$ using formulas $\bar{P}=\frac{\sum_{i=1}^{n} P i}{n} \bar{I}=\frac{\sum_{i=1}^{n} I i}{n}$, where $\bar{P}$ is the average of the reality score and $\bar{I}$ is the average of the expectation score. Result of calculation of $\bar{P}=3.07$ and $\bar{I}$-3.31. All data $\mathrm{I}$ and $\mathrm{P}$ entered in the Scatter Chart will get the results of the Importance Performance Analysis, as in Figure 3.

Table 7. Data on Customer Satisfaction Questionnaire Results

\begin{tabular}{clccccc}
\hline No & Indicators & Total of Expectations & Expectation Score (I) & Total of Reality & Reality Score(P) & Score S(I x P) \\
\hline 1 & Operate manual machine & 30 & 3,33 & 30 & 3,33 & 11,11 \\
\hline 2 & Operate and programming CNC Machine & 30 & 3,33 & 29 & 3,22 & 10,74 \\
\hline 3 & Technical design ability & 31 & 3,44 & 27 & 3,00 & 10,33 \\
\hline 4 & Using software design & 29 & 3,22 & 28 & 3,11 & 10,02 \\
\hline 5 & Automation & 27 & 3,00 & 25 & 2,78 & 8,33 \\
\hline 6 & Job or duty respect & 32 & 3,56 & 26 & 2,89 & 10,27 \\
\hline 7 & Discipline & 32 & 3,56 & 30 & 3,33 & 11,85 \\
\hline 8 & Honesty & 31 & 3,44 & 29 & 3,22 & 11,10 \\
\hline 9 & Caring & 30 & 3,33 & 28 & 3,11 & 10,37 \\
\hline 10 & Communication & 28 & 3,11 & 26 & 2,89 & 8,99 \\
\hline 11 & Collaboration & 29 & 3,22 & 29 & 3,22 & 10,38 \\
\hline 12 & Creativity & 28 & 3,11 & 25 & 2,78 & 8,64 \\
\hline
\end{tabular}




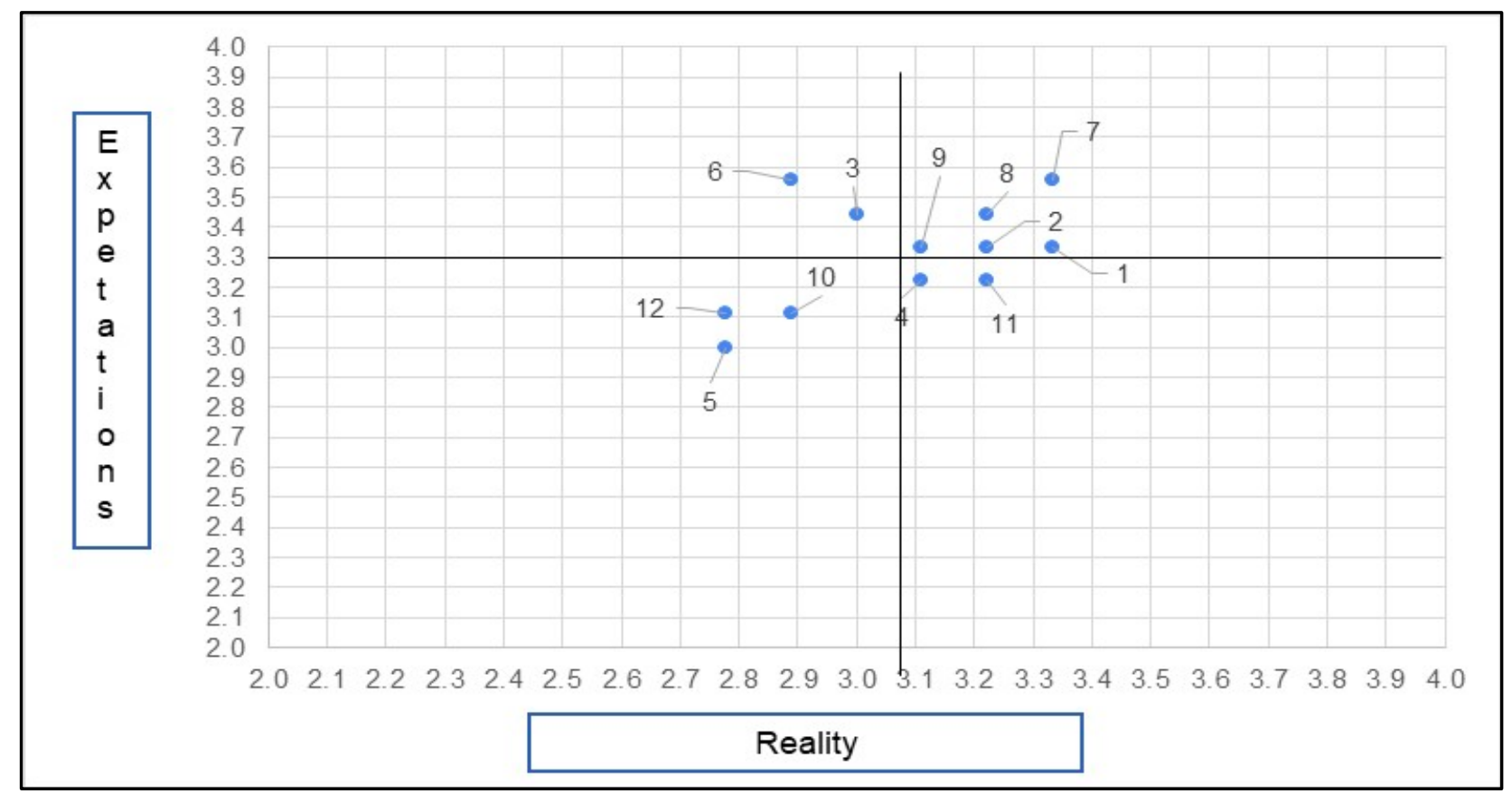

Figure 3. Data of Importance Performance Analysis

In Figure 3, Quadrant I (Concentrate Here) is an indicator of employability skills that have high importance to the industry, but graduates cannot meet these indicators. Some of the indicators included in the top priorities that are important to be improved are (1) job or duty respect, (2) technical design ability. Job or duty respect and technical design ability are important indicators of employability skills for the industry. VHS graduates do not have these two indicators as expected by the industry.

Aspects in Quadrant II (keep up the good work) are indicators that have high significance for the industry and have been fulfilled by school graduates. Some indicators in this quadrant are (1) discipline, (2) honesty, (3) caring, (4) operate and programming CNC Machine, (5) operate the manual machine. The five indicators must be maintained because users consider it very important and in accordance with is expected.

Quadrant III (low priority) are indicators considered to have a low level of importance or low priority by the industry. The aspects included in this quadrant are (1) communicative, (2) creativity (3) automation. These three indicators are not aspects of employability skills that are considered important by the industry. From the results of the data, the industry states although the aspects of communication, creativity, and automation have not been as expected.

Quadrant IV (possible overkill) are indicators of employability skills that are considered unimportant by the industry and VHS graduates strongly have these aspects. The aspects of this quadrant are (1) using software design, (2) collaboration. VHS graduates already have both of these aspects, even though the industry does not place these two aspects in the most important position.

\section{Conclusion}

Based on the data, it can be concluded that the VHS graduates in mechanical engineering expertise are not in line with the targets set by the Directorate of VHS. From the literature review, it is found that aspects of employability skills must be possessed by graduates. These aspects are (1) technical or knowledge-skills aspects and (2) Non-technical aspects or attitudes. The result of the satisfaction index is $76.98 \%$. This value is on the satisfied range, it means the industry expectations are full fill by graduates.

The results of the importance-performance analysis show the distribution of indicators. Indicators 1) discipline, (2) honesty, (3) caring, (4) operate and programing CNC Machine, (5) operate the manual machine (6) communicative, (7) creativity (8) automation accordance with the expectations of the industry. Schools must maintain the achievement of the eight indicators. Indicator job or duty respect and technical design ability is an important indicator that has not been fulfilled by VHS graduates. For the development of the learning process, these two indicators must get top priority from the school. The competency standard of technical design ability needs to be reviewed. Attitude aspects, especially respect for the task or job need to be considered by the school, especially to increase student motivation and interest in the work or assignment given.

\section{Acknowledgments}

Immensely grateful to Tabaguh Franklin Chi, Faculty of Biochemistry and Molecular Medicine, University of Oulu, Finlandia for comments on an earlier version of the manuscript, although any errors are our own and should not tarnish the reputations of these esteemed persons.

\section{References}

[1] Todd R.Kelly, J. Geoff K. J.H, E.S. 2019. Creating a $21^{\text {st }}$ Century Skill Survey Instrument for High School Students. American Journal of Educational Research. 7(8)583-590. 
[2] Ernst A. Hartmann, Marc Bovenschulte. 2014. Skills Needs Analysis for "Industry 4.0" Based on Roadmaps for Smart Systems. Jenewa . ILO.

[3] Presiden Repbulik Indonesia, Instruksi Presiden Republik Indonesia No. 9 Tahun 2016 tentang Revitalisasi Sekolah Menengah Kejuruan dalam Rangka Peningkatan Kualitas dan Daya Saing Sumber Daya Manusia Indonesia, Sekertariat Kabinet Republik Indonesia: Jakarta 2016.

[4] Hendra Kusuma.2018.Pengangguran RI 6,87 Juta Orang, Paling Banyak Lulusan SMK. Available from www.detik.com (accessed at $1^{\text {st }}$ September 2019).

[5] Yoga Sukmana.2018. Lulusan Banyak yang Menganggur, Apa Salah SMK Kita? Available from www.kompas.com (accessed at 1st September 2019).

[6] Indriaturahmi, Sudiyanto. 2016. Peran Dunia Usaha dan Dunia Industri Dalam Penyelanggaraan SMK Berbasis Kearifan Lokal di Kota Mataram. Jurnal Pendidikan Vokasi. 6(2):162-172.

[7] Irsan Roseno, Udik Budi Utomo. 2019. Efisiensi Eksternal Pendidikan Kejuruan di Kota Yogyakarta. Jurnal Akuntabilita Manajemen Pendidikan. 7(1):15-24.

[8] Ahmad Nur Arifin, Febrianto Amri R. 2017. Relevansi Kompetensi Teknik Gambar Manufaktur di SMK Muhammadiyah 2 Jatinom Terhadap Kebutuhan Industri. Jurnal Dinamika Vokasional Teknik Mesin. 2(2): 105-110.

[9] Khamdi Afandi, Bernardus Sentot Wijanarka.2019. Outcomes of Vocational High School in Machining Expertise in the Labor Market in Yogyakarta, Indonesia. American Journal of Educational Research. 7(9):599-603.

[10] Shiau Wei Chan,M.F Ahmad.2018. Employers Perception on Important Employability Skills in The Manufacturing Industry. International Journal of Engineering \& Technology. 7(2.29). $170-175$
[11] Endang Herawan. 2014. Pengembangan Model Manajemen Mutu Pendidikan Pada SMK di Kota Bandung. Jurnal Penelitian Pendidikan. 14(2): 199-208.

[12] Elih Mulyana. 2015. Kepuasan Pengguna Lulusan SMK. Desertasi. Universitas Pendidikan Indonesia.

[13] John A, Martila .1977. Importance-Performance Analysis. Journal of Marketing. 41(1): 77-79.

[14] Aprilyadi.2018.Target 75\% Lulusan SMK Langsung Bekerja. Available from http://psmk.kemdikbud.go.id/ (accessed at $22^{\text {nd }}$ september 2019).

[15] Kementrian Pendidikan dan Kebudayaan, Peraturan Menteri Pendidikan dan Kebudayaan Nomor 34 tahun 2018 Tentang Standart Nasional Pendidikan Sekolah Menengah Kejuruan/Madrayash Aliyah Kejuruan. Kementrian Pendidikan dan Kebudayaan Republik Indonesia: Jakarata 2018.

[16] Kementrian Pendidikan dan Kebudayaan, Peraturan Direktur Jenderal Pendidikan Dasar dan Menengah Kementrian Pendidikan dan Kebudayaan Nomor 07/D.D5/KK 2018 Tentang Struktur Kurikulum Sekolah Menengah Kejuruan (SMK)/Madrsah Aliyah Kejuruan (MAK): Jakarata 2018.

[17] Conference Board of Canada, Employabel Skills 2000+. Available from https://www.conferenceboard.ca/ (accessed at $2^{\text {nd }}$ September 2019).

[18] Dwi Agus Sudjimat. 2017. Emplyoability skills of Vocational High svhool Graduate Needed by Industri in Century XXI.Green Contrsuction and Engineering Educatiuon for Sustainable Future. API Conference Proceedings 1887.

[19] Bhote, K.R. 1996. Beyond Customer Satisfaction to Customer Loyality: The Key to Great Profitability. New York: AMA Membership Publications Division, American Management Association. 